\title{
Correlation of CD4 T Cell Count with Absolute Lymphocyte Count and Haemoglobin Levels in Human Immunodeficiency Virus Diseases
}

\author{
Authors \\ Dr Mukta Meel ${ }^{1}$, Dr Sunita Bhargava ${ }^{2}$, Dr Mukesh Kumar ${ }^{3}$ \\ ${ }^{1}$ MD Pathology, Senior Demonstrator, RNT Medical College, Udaipur \\ ${ }^{2}$ Professor and Head, RNT MC, Udaipur \\ ${ }^{3} \mathrm{MCH}$ Neurosurgery
}

\begin{abstract}
Aim: Depletion of CD4 cell count is a hallmark of disease progression in AIDS. CD4 cell count is essential for physicians to decide about the timing of initiation of antiretroviral therapy (ART) and for prophylaxis of opportunistic infections. WHO has recommended that, absolute lymphocyte count (ALC) of $\leq 1200 / \mu L$ can substitute CD4 cell count of $\leq 200 / \mu L$ in resource-constrained countries throughout the world.

Materials and Methods: This study was undertaken to know whether there is a correlation between CD4 cell count and ALC as well as haemoglobin in HIV-infected individuals. A single sample of blood was withdrawn for ALC and CD4 cell count. The samples received from December 1, 2011 to December 31, 2013 were analyzed.

Results: A total of 500 samples were collected from 500 patients and were analyzed. Results revealed that male:female ratio was $1.98: 1$ and their age ranged from 13 to 70 years. The median ALC was 1295 cells/ $\mu L$, whereas the CD4 cell count ranged from 21 to 452. The correlation coefficient between ALC and CD4 cell count was significant (0.348). There were 207 patients with an ALC of $\leq 1200 / \mu L$ of whom $81.16 \%$ patients had CD4 cell count $\leq 200 / \mu \mathrm{L}$ (true positive) and $18.84 \%$ had CD4 cell count $>200 / \mu \mathrm{L}$ (false positive). There were 293 patients with an ALC of $>1200 / \mu \mathrm{L}$ of whom $60.41 \%$ had CD4 cell count $>200 / \mu L$ (true negative) and $39.59 \%$ had CD4 cell count $\leq 200 / \mu L$ (false negative). Taking ALC of $\leq 1200 / \mu L$ as a predictor of CD4 cell count $\leq 200 / \mu L$, the sensitivity of the test was $59.15 \%$ and specificity was $81.94 \%$. The positive predictive value was $81.15 \%$, negative predictive value was $60.40 \%$, and Out of five hundred cases ALC and Hb could be correlated with CD4 cell count in 243 cases, amongst which 138 cases had ALC $\leq 1200 \mathrm{cells} / \mathrm{mm}^{3}, \mathrm{Hb} \leq 10$ gm\% and CD4 cell count $\leq 200$ cells $/ \mathrm{mm}^{3}$, with accuracy of $81.66 \%$.

Conclusion: We found that an ALC of $\leq 1500 / \mu L$ has higher sensitivity (80.63\%) for a CD4 cell count of $\leq$ $200 / \mu L$. The ALC was found to be significantly cost-effective in our setup but chances of missing out patients requiring ART was 1 in 5 using the WHO guidelines.
\end{abstract}

KEY WORDS: Absolute lymphocyte count, AIDS, CD4 cell count, HIV, India

\section{INTRODUCTION}

According to UNAIDS, 34 million people have been infected by the human immunodeficiency virus (HIV). Most people living with HIV are from developing countries with less than $5 \%$ receiving antiretroviral therapy ${ }^{(1)}$.
However, it is estimated that in developing countries, 9.7 million people are in immediate need of antiretroviral therapy (ART) and regrettably only 2.99 million $(31 \%)$ are receiving the drugs. Currently, the existing number of CD4+ $\mathrm{T}$ lymphocytes is considered the best marker of 
the immediate state of HIV-induced immune impairment of a patient with HIV infection that would warrant initiation of ART ${ }^{(2)}$.

Depletion of CD4 cell count is a hallmark of disease progression in AIDS. CD4 cell count is essential to decide about the timing of initiation of antiretroviral therapy (ART) and for prophylaxis of opportunistic infections. Measurement of viral load and CD4 cell count are important tests in the management of HIV-infected individuals. With the progression of the disease, there is a gradual depletion of CD4 cell count. Prophylaxis for opportunistic infection is also dependent on CD4 cell count, especially when CD4 falls below $200 / \mu \mathrm{L}$ or CD4<20\%. The present recommendation for testing CD4 cell count is every 4-6 months, however, the test is costly and the equipment required are sophisticated ${ }^{(3)}$.

Current recommendations in Western countries for initiation and monitoring of HAART (highly active anti-retroviral therapy) in patients infected with HIV are based on CD $4{ }^{+} \mathrm{T}$-cell counts and plasma HIV RNA levels (viral load). However, these standard methods require highly trained personnel and heavy initial investment in laboratory instrumentation. Owing to the everexpanding access and increasing availability of generic highly active anti-retroviral therapy (HAART) in resource-limited settings like in India, there is a need to evaluate alternate markers like absolute lymphocyte count (ALC) as a surrogate for CD4 counts as the cost of CD4 count estimation is 45 times higher than ALC ${ }^{(4)}$.

WHO has suggested that total lymphocyte counts (TLC) could work as a potential marker for immunosuppression whenever CD4 counts are unavailable, because TLC is easily obtained from routine complete blood cell counts by multiplying the percentage of lymphocytes by the whiteblood-cell count ${ }^{(5)}$.

WHO has also recommended that irrespective of the CD4 cell count, ART can be started on patients who have WHO stage III or IV disease and on patients who have WHO stage II disease with an ALC of $\leq 1200 / \mu \mathrm{L}$ (which can substitute
CD4 cell count of $\leq 200 / \mu \mathrm{L}$ ), especially in resource-constrained areas ${ }^{(3)}$.

The utility of the TLC for predicting a low CD4 count has been found to improve when considered in combination with the haemoglobin level. Anaemia, which is frequent in persons with HIV infection, predicts clinical prognosis independent of CD4 count and viral load ${ }^{(6)}$.

While the rates of decrease in $\mathrm{Hb}$ have been reported to correlate with falling CD4 counts, there have been suggestions that increase in haemoglobin was predictive of treatment success when combined with an increase in TLC ${ }^{(7)}$.

The aim of our study is to evaluate clinical illness and ALC as surrogate markers of the CD4 count in HIV-infected persons being considered for ART as well as to find a correlation between ALC, haemoglobin and CD4 cell count in HIV infected individuals in our economic setup.

\section{MATERIAL AND METHODS}

This study was undertaken on AIDS patients attending the ART centre of Maharana Bhupal Govt. Hospital, Microbiology Department and Haematology section of Pathology Department, RNT Medical College, Udaipur.

Detailed history of HIV infected individuals with their informed consent was carried-out in the following manner-

1. Bio data of patient (including age, sex, occupation and marital status).

2. Significant personal, past and family history.

A sample of venous blood from HIV-infected individuals was withdrawn ( $5 \mathrm{ml}$ in EDTA bulbs) with disposable syringe and 21 gauge needle, with complete aseptic precautions for complete blood count $(\mathrm{CBC})$ and $\mathrm{CD} 4$ count. CD4 count was carried out by flow cytometry and $\mathrm{CBC}$ was done by fully automated haematology analyzer.

Statistical analysis including sensitivity, specificity, positive predictive value, negative predictive value and accuracy was calculated for absolute lymphocyte count (ALC) and haemoglobin $(\mathrm{Hb})$ taking $\mathrm{CD} 4$ cell count as standard. 


\section{RESULTS}

The present study was carried out on five hundred HIV- infected individuals whoattended the ART Centre of M.B. Govt. Hospital and thereafter the Microbiology department and Haematology section of Pathology Department, RNT Medical College, Udaipur.

The age of HIV individuals in the present study varied from 13 to 70 years with mean $( \pm \mathrm{SD})$ of 36 years $( \pm 10.1)$ and median age was 35years. Haemoglobin ranged from 4.8 to 13.8 gm\% with mean $( \pm \mathrm{SD})$ of $9.6 \mathrm{gm} \%( \pm 0.77)$.

The total leucocyte count (TLC), absolute lymphocyte count and CD4 cell count ranged from 1100 to 10800 cells $/ \mathrm{mm}^{3}, 84$ to 3128 cells $/ \mathrm{mm}^{3}$ and 21 to 452 cells $/ \mathrm{mm}^{3}$ respectively and median $( \pm$ SEM $)$ value was $4800( \pm 63.7)$, $1295( \pm 21.2), 173( \pm 4.1)$ respectively (Table 1$)$.

Table 1 Demographic and laboratory profile of HIV infected individuals in the present study $(\mathrm{n}=500)$

\begin{tabular}{|l|l|l|l|l|l|}
\hline & $\begin{array}{l}\text { Age } \\
(\text { years })\end{array}$ & $\begin{array}{l}\mathrm{Hb} \\
(\mathrm{gm} / \mathrm{dl})\end{array}$ & $\begin{array}{l}\text { TLC } \\
\left(\text { cells } / \mathrm{mm}^{3}\right)\end{array}$ & $\begin{array}{l}\text { ALC } \\
\left(\text { cells/mm }{ }^{3}\right)\end{array}$ & $\begin{array}{l}\text { CD4 Count } \\
(\text { cells/mm })\end{array}$ \\
\hline Minimum & 13 & 4.8 & 1100 & 84 & 21 \\
\hline Maximum & 70 & 13.8 & 10800 & 3128 & 452 \\
\hline Mean & 36 & 9.6 & 5052 & 1397 & 179 \\
\hline Range & 57 & 9.0 & 9700 & 3044 & 439 \\
\hline Median & 35 & 9.6 & 4800 & 1295 & 173 \\
\hline Std. deviation & 10.1 & 0.77 & 1425 & 476 & 93.6 \\
\hline Std. Error of Mean & 0.45 & 0.034 & 63.7 & 21.2 & 4.1 \\
\hline
\end{tabular}

Male female ratio was 1.98:1. The affected males were mostly farmers and drivers. Amongst the females, housewives were chiefly affected.

In our study most of the HIV infected individuals were married. Majority of the HIV patients had haemoglobin $\leq \operatorname{logm} \% .76 .2 \%$ of the patients had TLC count of more than 4000 cells $/ \mathrm{mm}^{3}$.

In the present study the absolute lymphocyte count ranged from 84 to 3128 cells $/ \mathrm{mm}^{3}$ and 293 out of $500(58.6 \%)$ patients had ALC > 1200 cells $/ \mathrm{mm}^{3}$.

The range of CD4 cell count in the present study was 21 to $452 \mathrm{cell} / \mathrm{mm}^{3}$. In $56.8 \%$ of the cases CD4 cell count was $\leq 200$ cells $/ \mathrm{mm}^{3}$.

Statistical analysis of ALC $\left(\leq 1200\right.$ cells $\left./ \mathrm{mm}^{3}\right)$ with CD4 cell count $\left(\leq 200\right.$ cells $\left./ \mathrm{mm}^{3}\right)$ was performed in which 177 cases were true negative while 168 cases were true positive (Table 2).
Table 2 Statistical correlation of ALC with CD4 cell count in the present study

\begin{tabular}{|l|l|l|}
\hline \multirow{2}{*}{ ALC $\left(\right.$ cells $\left./ \mathrm{mm}^{3}\right)$} & \multicolumn{2}{|l|}{ CD4 cell count $\left(\right.$ cells $\left./ \mathrm{mm}^{3}\right)$} \\
\cline { 2 - 3 } & $\leq 200$ & $>200$ \\
\hline$\leq 1200$ & $168(\mathrm{TP})$ & $39(\mathrm{FP})$ \\
\hline$>1200$ & $116(\mathrm{FN})$ & $177(\mathrm{TN})$ \\
\hline Total & 284 & 216 \\
\hline
\end{tabular}

Sensitivity and specificity of absolute lymphocyte count $\left(\leq 1200\right.$ cells $\left./ \mathrm{mm}^{3}\right)$ in detecting CD4 T cell count $\left(\leq 200\right.$ cells $\left./ \mathrm{mm}^{3}\right)$ was $59.15 \%$ and $81.94 \%$ respectively. Positive predictive value and negative predictive value was $81.15 \%$ and $60.40 \%$. 
Statistical analysis to observe correlation of ALC $\left(\leq 1500\right.$ cells $\left./ \mathrm{mm}^{3}\right)$ with CD4 cell count 200cells/mm3 was done which show that 229 cases were true positive while 120 cases were true negative (Table 3).

Table 3 Statistical correlation of ALC with CD4 cell count in the present study

\begin{tabular}{|l|c|c|}
\hline \multirow{2}{*}{ ALC $\left(\right.$ cells $\left./ \mathrm{mm}^{3}\right)$} & \multicolumn{2}{|c|}{ CD4 cell count $\left(\right.$ cells $\left./ \mathrm{mm}^{3}\right)$} \\
\cline { 2 - 3 } & $\leq 200$ & $>200$ \\
\hline$\leq 1500$ & $229(\mathrm{TP})$ & $96(\mathrm{FP})$ \\
\hline$>1500$ & $55(\mathrm{FN})$ & $120(\mathrm{TN})$ \\
\hline Total & 284 & 216 \\
\hline
\end{tabular}

Sensitivity, specificity, positive predictive value and negative predictive value of absolute lymphocyte count $\left(\leq 1500\right.$ cells $\left./ \mathrm{mm}^{3}\right)$ in detecting CD4 T cell count $\left(\leq 200\right.$ cells $\left./ \mathrm{mm}^{3}\right)$ was $80.63 \%$ $, 55.56 \%, 70.46 \%$ and $68.57 \%$ respectively.

Out of five hundred cases ALC and $\mathrm{Hb}$ could be correlated with CD4 cell count in 243 cases, amongst which 138 cases had ALC $\leq 1200$ cells $/ \mathrm{mm}^{3}, \mathrm{Hb} \leq 10 \mathrm{gm} \%$ and $\mathrm{CD} 4$ cell count $\leq$ 200 cells $/ \mathrm{mm}^{3}$, with accuracy of $81.66 \%$.

Out of the 74 cases with ALC > 1200 cells $/ \mathrm{mm}^{3}$, $\mathrm{Hb}>10 \mathrm{gm} \%$, only 43 cases revealed CD4 cell count $>200$ cells $/ \mathrm{mm}^{3}$, with accuracy of $58.11 \%$ Sensitivity and specificity of hemoglobin in predicting CD4 T cell count $\left(\leq 200\right.$ cells $\left./ \mathrm{mm}^{3}\right)$ was $78.87 \%$ and $24.54 \%$ respectively.In our study, it was observed that the $\mathrm{P}$ value was less than 0.01 suggesting the significant relationship between ALC and CD4 T cell count in HIV infected individuals. On application of Pearson correlation test in the present study, correlation coefficient value ' $r$ ' was 0.348 .

Application of Pearson correlation test and $\mathrm{P}$ value showed that there was a significant positive relationship between ALC and CD4 T cell count.
Thus, on analysis of the results of the present study a statistical significant correlation between ALC and CD4 cell count was seen.

\section{DISCUSSION}

HIV disease continues to be a leading cause of morbidity and mortality and opportunistic diseases remain the most frequent cause of complications among HIV-infected patients. Rates of opportunistic diseases increase substantially with worsening immune status, as determined by CD4 counts ${ }^{(8)}$.

For effective monitoring and management of HIV infection the CD4 +T-lymphocyte (CD4) count is considered the best laboratory marker, but because of expensive instruments and kits it has limited availability in both resource-poor and developed countries ${ }^{(9)}$.

The CD4+ T-lymphocyte count is considered the best laboratory marker of HIV-1 infection and serial CD4 count determinations are commonly used to monitor the degree of HIV-induced immunosuppression. Low CD4 counts are indicative of decreased cellular immunity, and are associated with increased risk of developing AIDS or death. Normal CD4 count is 500 to 1200 cell/ $\mu 1$. A decrease in the total CD4 lymphocyte count below $500 / \mu \mathrm{L}$ progresses to the development of clinical AIDS, and a drop below $200 / \mu \mathrm{L}$ not only defines AIDS, but also indicates a high probability for the development of AIDSrelated opportunistic infections and/or neoplasms. The risk of death from HIV infection is low, if CD4 level above $200 / \mu \mathrm{L}^{(10)}$.

In resource-constrained developing countries where the majority of people infected with HIV are living, the facilities for CD4 cell count testing may not be available/ affordable. To overcome this problem, WHO has recommended that irrespective of the CD4 cell count, ART can be started on patients who have WHO stage III or IV disease and on patients who have WHO stage II with an ALC of $<1200 / \mu 1$ (which can substitute CD4 cell count of $<200 / \mu 1)^{(11)}$.

In a recent study conducted in Ghana, in remote and deprived areas, where there was scarcity of 
laboratory technologies, a strong relationship between CD4 $<200$ cells $/ \mathrm{mm}^{3}$ and TLC was found, thus using TLC as a surrogate marker ${ }^{(12)}$.

To improve the sensitivity of surrogate markers and to initiate the use of HAART in resource limited settings, a study carried out by Spacek et al (2003) revealed that Absolute Lymphocyte count below 1200 cells/cumm was associated with CD4 cell counts $<200$ cells/cumm as in the WHO guidelines, but sensitivity was low. Adding haemoglobin $(\mathrm{Hb})$ estimation to Absolute Lymphocyte count increased the sensitivity, thereby reducing the risk of false-negative results. Anaemia associated with HIV/AIDS is independently associated with the progression of disease, mortality, and CD4 lymphocyte counts of $<200$ cells $/ \mathrm{mm}^{3}$. The accelerated decline in haemoglobin preceding the development of AIDS defines a point at which HAART could be initiated. The initiation of HAART improves the anaemia of HIV infection.

\section{CONCLUSION}

Our study suggests that ALC is a good surrogate test for HIV management and has a significant strong positive correlation with CD4 cell count. Using WHO guidelines, with a cutoff $\leq 1200 / \mu \mathrm{L}$ for ALC we would be able to treat $82 \%$ of patient requiring ART. The test is cost-effective and the funds saved can be utilised for the initiation of ART. We would recommend a higher cutoff value of ALC, that is, $1500 / \mu \mathrm{L}$, which would pick up maximum number of patients having CD4 count < $200 / \mu$ L. However in our studyan attempt was also made to find another alternative surrogate marker for CD4 cell count. The haemoglobin level of the HIV patients was measured and correlated with CD4 T Cell count but was not specific thus revealing that $\mathrm{Hb}$ alone cannot predict $\mathrm{CD} 4 \mathrm{~T}$ cell count. However it was observed that a combination of ALC along with haemoglobin could be a better predictor of the CD4 cell count.

\section{REFERENCE}

1. UNAIDS: Global Report for Epidemic of AIDS; Geneva, 2010.
2. Buseri FI, Mark D, Jeremiah ZA: Evaluation of Absolute Lymphocyte Count as a Surrogate marker for CD4+ cell count for the Initiation of Antiretroviral Therapy (ART) in Resource-limited Settings. International Journal of Biomedical Laboratory Science 1(2); 44-49, 2012.

3. Kakar A, Beri R, Gogia A, Byotra SP, Prakash V, Kumar S, Bhargava M: Absolute lymphocyte count: A costeffective method for monitoring HIVinfected individuals. Ind $\mathbf{J}$ PatholMicrobiol 54; 107-111, 2011.

4. Srirangaraj S and Venkatesha D: Absolute lymphocyte count as a surrogate marker for CD4 counts after six months of HAART initiation in a resource-limited setting in India. Indian $\mathrm{J}$ Med Res 135; 895-900, 2012.

5. Flanigan TP,

Kumarasamy N, Mahajan AP, Hemalatha R, Mayer KH, Carpenter CC, Thyagarajan SP, Soloman S: Total lymphocyte count (TLC) is a useful tool for the timing of opportunistic infection prophylaxis in India and other resource-constrained countries. J Acquir Immune DeficSyndr 31(4); 378-83, 2002.

6. Costello C: Haematological abnormalities in human immunodeficiency virus (HIV) disease. J ClinPathol 41; 711-715, 1988.

7. Sen S, Vyas A, Sanghi S, Shanmuganandan K, Gupta RM, Kapila K, Praharaf AK, Kumar S, Batra RB: Correlation of CD4+ $\mathrm{T}$ cell count with total lymphocyte count and haemoglobin in human immunodeficiency virus type-1 diseases. Medical J Armed Force India 67; 15-20, 2011.

8. Losina E, Yazdanpanah Y, Deuffic-Burban S, Wang B, Wolf LL, Messou E, Gabillard D, Seyler C, Freedberg KA, Anglaret X: The Independent Effect of Highly Active Antiretroviral Therapy on Severe Opportunistic Disease Incidence and Mortality in HIV infected Adults in Cote 
d'Ivoire. AntivirTher 12(4); 543-551, 2007.

9. Fahey JL, Taylor JMG, Detels R, Prince $\mathrm{H}$, Weaver $\mathrm{M}$ : The prognostic value of cellular and serologic markers in infection with human immunodeficiency virus type 1. N Engl J Med 322; 166-72, 1990.

10. Phillips AN, Elford J, Sabin C, Bofill M, Janossy G, Lee CA: Immunodeficiency and the risk of death in HIV infection. $\mathrm{J}$ Am Med Assoc 268; 2662-66, 1992.

11. WHO: Scaling up antiretroviral therapy in resource-limited settings: treatment guidelines for a public health approach 2003 revision. Switzerland, WHO Press; 2004.

12. Obirikorang $\mathrm{C}$ and Yeboah FA: Blood haemoglobin measurement as a predictive indicator for the progression of HIV/AIDS in resource-limited setting. Journal of Biomedical Science 16; 102, 2009. 